\title{
Micropropagation of Eclipta alba using Humic Acid as Media Component ${ }^{\dagger}$
}

\section{Ramya M. ${ }^{1, *}$}

1 Department of Biotechnology, Sathyabama Institute of Science and Technology, Jeppiaar Nagar, Rajiv Gandhi Salai, Chennai - 600 119, Tamil Nadu, India

* Correspondence: ramyarama1999@gmail.com;

$\dagger$ Presented at International e-Conference on Bioengineering for Health and Environment (ICBHE 2020)

Received: 5.07.2020; Revised: 10.07.2020; Accepted: 12.07.2020; Published: 15.07.2020

Abstract: The potential of humic acid as a growth supplement in micropropagation of eclipta alba is reported in the present investigation. Eclipta alba explants were grown in MS media with BAP and Kinetin as growth factors, and it has been observed that BAP was more effective for in vitro regeneration of the explants. On the other hand, when humic acid was supplemented along with the growth factors, there is an increase in the shoot proliferation within a reduced period of time. The optimum concentration of humic acid required was found to be $300 \mathrm{mg} / 100 \mathrm{ml}$ for the effective growth of explants. This study, therefore, supports the use of humic acid as a suitable growth supplement in micropropagation studies.

Keywords: Media component; micropropagation; progeny plants; tissue culture; Eclipta alba.

(C) 2020 by the authors. This article is an open-access article distributed under the terms and conditions of the Creative Commons Attribution (CC BY) license (https://creativecommons.org/licenses/by/4.0/).

\section{Funding}

This research received no external funding.

\section{Acknowledgments}

This research has no acknowledgment.

\section{Conflicts of Interest}

The authors declare no conflict of interest. 